\title{
Processing of fish offal waste through fermentation utilizing whey as inoculum
}

\author{
Ayan Samaddar · Anilava Kaviraj
}

Received: 3 June 2013/ Accepted: 20 January 2014 / Published online: 20 February 2014

(C) The Author(s) 2014. This article is published with open access at Springerlink.com

\begin{abstract}
Background Lactic acid fermentation is a strong tool to convert biodegradable wastes into food ingredients for animal husbandry. Experiments were made to evaluate if lactic acid bacteria of whey, a by-product of dairy industry, could be exploited to ferment fish offal waste (FOW) and to compare the effectiveness of whey as fermentation inoculum with that of a pure culture of Lactobacillus acidophilus.

Results Although fermentation of FOW by whey required 5 days to complete in contrast to 3 days required for fermentation by $L$. acidophilus, removal of hazardous microorganisms like Staphylococcus, Clostridium and coliform bacteria was better in the whey-fermented fish offal (WFFO) than that of L. acidophilus-fermented fish offal (LAFFO). Protein and lipid contents of the wastes were almost completely recovered in both the fermented products, with WFFO showing a higher amount of free amino acid than the LAFFO. Both the fermented products were stable against the growth of mould and yeast.

Conclusion It is concluded that whey is a viable and easily available inoculum to ferment FOW and convert it to a microbiologically safe and nutrient-rich end product suitable for use as feed supplement in animal feed formulation.
\end{abstract}

Keywords Fermentation - Lactic acid bacteria - Nutrient recovery · Organic acids · Preservation

\footnotetext{
A. Samaddar $(\bowtie) \cdot$ A. Kaviraj

Department of Zoology, University of Kalyani,

Kalyani 741235, W.B., India

e-mail: ayansam.2009@gmail.com

A. Kaviraj

e-mail: akaviraj@gmail.com
}

\author{
List of abbreviations \\ AA Acetic acid \\ ANOVA Analysis of variance \\ FOW Fish offal waste \\ LA Lactic acid \\ LAB Lactic acid bacteria \\ LAFFO Lactobacillus acidophilus-fermented fish offal \\ LSD Least significant difference \\ PDA Potato dextrose agar \\ SPC Standard plate count \\ WFFO Whey-fermented fish offal \\ WSC Water-soluble carbohydrates
}

\section{Introduction}

Fermentation is a useful biotechnological tool to recover essential nutrients contained in fish offal waste (FOW) and recycle them as feed stuff for fish (Mondal et al. 2007, 2008). It provides dual benefit: protection of environment from the risk of disposal related pollution including microbial contamination and reduction in the cost of aquaculture feed production. Fermented FOW is used as an alternative to fishmeal, the chief source of protein and most costly ingredient in aquaculture diet (Samaddar et al. 2011). Literature available on fermentation of vegetable (Bairagi et al. 2002) and animal wastes (Mondal et al. 2007, 2008) for recycling them as feed stuff indicate that there is scope to improve the fermentation technique towards reducing the time of fermentation for minimizing nutrient degradation rate and improving the quality of fermented products with economic and environmental benefits. Lactic acid bacteria (LAB) are widely employed 
in fermentation for animal feed production, their preservation (Chou and Weimer 1999; Driehuis et al. 2001; Nwad et al. 2008) and digestibility increment (Vidotti et al. 2002).

Milk and fermented dairy products are good source of LAB (Delves-Broughton 1990; Stiles 1996). Whey is a byproduct of fermented and coagulated dairy products and is also a potential pollutant of terrestrial and aquatic environment (Goyal and Gandhi 2009; Gonzalez-Siso 1996; Marwaha and Kennedy 1988). However, whey is a potential source of LAB and is a viable inoculum for fermentation. In recent years there have been some research efforts to develop new technology to utilize whey or its constituents for other purposes so that pollution from these sources is minimized. The objective of the present study was to quantify LAB of whey and to evaluate if it could be exploited to ferment FOW successfully. Lactobacillus acidophilus is a widely applied LAB for fermentation because of its homofermentative nature rendering quick acidification along with strong anti-microbial effects against hazardous microorganisms (Weinberg and Muck 1996; Pyar et al. 2011). Therefore, fermentation ability of whey was compared with that of pure culture of L. acidophilus in the present study.

\section{Methods}

\section{Collection of samples}

Samples of FOW composed of mainly viscera of carps, were collected from the local retail fish markets in sterilized containers. The portion of guts contained in the fish offal was carefully uncoiled and gut materials were removed using clean water. Whey was collected as liquid by-product from a local dairy product farm that commercially produces yogurt from milk. The process of yogurt production in brief includes boiling of milk followed by cooling to $40 \pm 2{ }^{\circ} \mathrm{C}$ temperature and addition of starter culture from previous stock of yogurt. The milk is transformed to yogurt within 5-6 h and whey is separated as liquid by-product. Initially random samples of whey were collected from three different local dairy product farms and were subjected to determine population of LAB, the key group of microorganisms to be exploited in the present study. Since quantity of LAB did not show any significant variation between the sources, we selected only one source of whey for the final study. Samples of fresh whey were collected in sterilized screw cap bottles, and were transported to the laboratory for use as inoculum in the fermentation of FOW. Cane molasses, used as a source of fermentable carbohydrate for microorganisms involved in the fermentation, was collected from the local market in sterilized containers. FOW, whey and cane molasses were transported to the laboratory in ice buckets to avoid further contamination and were subjected to microbiological analyses to determine their hygienic condition before these were used in the fermentation process. Detailed analytical methods have been described below. Only freshly collected samples of FOW, whey and cane molasses were used for fermentation.

\section{Fermentation process}

Fermentation of FOW was carried out in 11 Erlenmeyer flasks, each containing $400 \mathrm{~g}$ of fermentation mixture. The mixture contained $80 \%$ of chopped fish offal, $15 \%$ of cane molasses and $5 \%$ of fermentation inoculum containing either freshly collected whey or actively growing culture $\left[10^{9}\right.$ colony forming units $\left.(\mathrm{CFU}) / \mathrm{ml}\right]$ of $\mathrm{L}$. acidophilus (NCIM 2903) procured from the National Collection of Industrial Microorganisms (NCIM), National Chemical Laboratory, Pune, India. The fermentation technique was standardized following the method described by Hammoumi et al. (1998). Biochemical compositions of fish offal waste (FOW), cane molasses and fresh whey were determined before these were added to the mixture. The mixture was also subjected to biochemical analyses before the incubation was started. All analyses were made following standard analytical methods described below. The fermentation mixture (mean moisture level $=70 \%$ ) was incubated at $35^{\circ} \mathrm{C}$. Several replicates were maintained for each of the two fermentation mixture. Every day one replicate from each group was opened and $\mathrm{pH}$, water soluble carbohydrates (WSC) and quantity of lactic acid (LA) and acetic acid (AA) produced in the fermentation mixture were determined. Determinations were continued till the mixture attained a $\mathrm{pH}$ value in between 4.0 and 4.2, after which the fermentation was discontinued. The entire experiment was repeated thrice.

The fermented products were subjected to microbiological and biochemical analyses. Stability of the dry fermented products against growth of mould and yeast was also checked and compared with that of the dried FOW. Detailed analytical methods are described below.

Analytical methods

\section{Microbiological analyses}

Determinations of standard plate count (SPC), population of LAB, yeast and hazardous microorganisms such as total and faecal coliform, Staphylococcus and Clostridium were made in the fresh FOW, fresh whey, cane molasses as well as in the two fermented products, whey-fermented fish offal (WFFO) and L. acidophilus-fermented fish offal 
(LAFFO). Ten grams of each sample was blended with $90 \mathrm{ml}$ of saline water $(\mathrm{NaCl}, 0.85 \% \mathrm{w} / \mathrm{v})$, diluted serially (10-folds), plated with $1 \mathrm{ml}$ of the suspension in appropriate media using pour plating technique (Cappuccino and Sherman 2007) and incubated at the appropriate temperature. The colonies that appeared on the selected plates after incubation were enumerated as $\mathrm{CFU} / \mathrm{g}$ or $\mathrm{ml}$ of sample. Samples were incubated in Plate count agar (Standard methods agar) (HiMedia, Mumbai, India) at $30{ }^{\circ} \mathrm{C}$ for 2-3 days for enumeration of SPC, in potato dextrose agar (PDA) (HiMedia, Mumbai, India) acidified by LA solution to $\mathrm{pH} 3.5$ at $30{ }^{\circ} \mathrm{C}$ for $72 \mathrm{~h}$ for enumeration of yeast, in Lactobacillus MRS agar (HiMedia, Mumbai, India) at $30{ }^{\circ} \mathrm{C}$ for $48 \mathrm{~h}$ for enumeration of LAB, Lactobacillus selection agar (HiMedia, Mumbai, India) at $30{ }^{\circ} \mathrm{C}$ for $48 \mathrm{~h}$ for enumeration of Lactobacillus sp., in MacConkey broth (HiMedia, Mumbai, India) supplemented with agar, at $37{ }^{\circ} \mathrm{C}$ for $24 \mathrm{~h}$ for enumeration of total coliform bacteria and again in the same media at $44{ }^{\circ} \mathrm{C}$ for $24 \mathrm{~h}$ for determination of faecal coliform bacteria. For enumeration of Staphylococcus, the samples were incubated in mannitol salt agar (HiMedia, Mumbai, india) at $37^{\circ} \mathrm{C}$ for $24 \mathrm{~h}$. Yellow colonies were enumerated and checked by Gram stain and catalase reactions. For enumeration of Clostridium colonies, the samples were heated at $80{ }^{\circ} \mathrm{C}$ for $10 \mathrm{~min}$, immediately followed by cooling on ice water. The cooled samples were serially diluted, plated and incubated at $44{ }^{\circ} \mathrm{C}$ for $24 \mathrm{~h}$ in reinforced clostridial agar (HiMedia, Mumbai, India).

\section{Biochemical analyses}

The samples were diluted with water (1:10) for determination of $\mathrm{pH}$ in a direct reading digital $\mathrm{pH}$ meter. WSC was determined by modified spectrophotometric method described by Murphy et al. (2007). For determination of LA and AA, samples were diluted with water (1:10), homogenized and filtered through Whatman-2 filter paper. The filtrate was centrifuged at $14,400 \mathrm{~g}$ for $15 \mathrm{~min}$ and the supernatant was further filtered through $0.45 \mu \mathrm{m}$ membrane filter. LA in the filtrate was determined by the method of McHugh et al. (2006) in an HPLC system (Waters) using a $4.6 \times 250 \mathrm{~mm}, 5 \mu \mathrm{m}$, column (ZORBAX Rx-C18; Agilent Technologies), a Waters 2996 photodiode array UV detector, programmed at $210 \mathrm{~nm}$ and a mixture of acetonitrile:buffer (3:97) as the mobile phase with a flow rate of $1.2 \mathrm{ml} / \mathrm{min}$. The buffer used was $25 \mathrm{mM} \mathrm{KH}_{2} \mathrm{PO}_{4}$ (adjusted to $\mathrm{pH} 2.5$ by $\mathrm{H}_{3} \mathrm{PO}_{4}$ ). AA in the filtrate was determined in the same HPLC system, but $50 \mathrm{mM} \mathrm{KH}_{2} \mathrm{PO}_{4}$ (adjusted to $\mathrm{pH} 2.5$ by $\mathrm{H}_{3} \mathrm{PO}_{4}$ ) buffer alone was used as the mobile phase with a flow rate of $1 \mathrm{ml} / \mathrm{min}$ (Dremetsika et al. 2005). Retention time of the standard LA and AA was found, respectively, at 2.2 and $2.9 \mathrm{~min}$ (Fig. 1). The quantity of both LA and AA in the samples was determined using Empower software associated with the HPLC system.

Proximate compositions were determined by AOAC methods (Helrich 1990). Samples were oven dried at $55-60{ }^{\circ} \mathrm{C}$ for $18-20 \mathrm{~h}$ before analysis. Moisture was determined by oven drying at $105{ }^{\circ} \mathrm{C}$ for $24 \mathrm{~h}$; crude protein (nitrogen $\times 6.25$ ) was determined by Kjeldahl method after acid hydrolysis; lipid was extracted by petroleum ether (boiling point $40-60{ }^{\circ} \mathrm{C}$ ) for $7-8 \mathrm{~h}$ in a Soxhlet apparatus followed by determination of lipid gravimetrically; crude fibre was determined as loss on ignition of dried lipid-free residues after digestion with $1.25 \% \mathrm{H}_{2} \mathrm{SO}_{4}$ and $1.25 \% \mathrm{NaOH}$ and ash was determined by combustion at $550{ }^{\circ} \mathrm{C}$ in a muffle furnace till a constant weight was achieved. Nitrogen-free extract (NFE) was calculated by taking the sum of values for crude protein, crude fibre, crude lipid, moisture and ash and subtracting this from 100. Free amino acid was determined by the method of Moore and Stein (1948) using ninhydrin reagent dissolved in methyl cellosolve (2-methoxyethanol).

Aerobic stability against mould and yeast

The stability of the fermented products and dried FOW against growth of mould and yeast was checked by a short experiment. Ten grams of dry sample, fermented product or FOW was taken in a plate of $90 \mathrm{~mm}$ diameter, spread in a very thin layer and kept in open air or covered by a lid in the laboratory. Two control sets, one containing PDA and another containing PDA acidified by LA to $\mathrm{pH} 3.5$ (acidified PDA) in similar plates, were also maintained. The temperature and humidity were recorded during the experiments. Samples of the fermented products, dried FOW and the control media were taken out from the respective plates after $1 \mathrm{~h}$ and 5 days of incubation, diluted serially $(1: 10)$ in saline water $(\mathrm{NaCl}, 0.85 \% \mathrm{w} / \mathrm{v})$, plated following spread plating technique and incubated for 3 days at $30{ }^{\circ} \mathrm{C}$ separately in two media: one containing PDA and another containing acidified PDA to grow a mixture of mould and yeast (M\&Y) and only yeast (Y), respectively. CFU were enumerated in the plates after 3 days.

\section{Statistical analyses}

Single factor analysis of variance followed by least significant difference test (Gomez and Gomez 1984) were employed to test significant difference in $\mathrm{pH}$, WSC, LA and AA of the two fermentation mixtures between initial and terminal days of fermentation as well as between the two final fermented products (WFFO and LAFFO). Significant differences in biochemical compositions between 

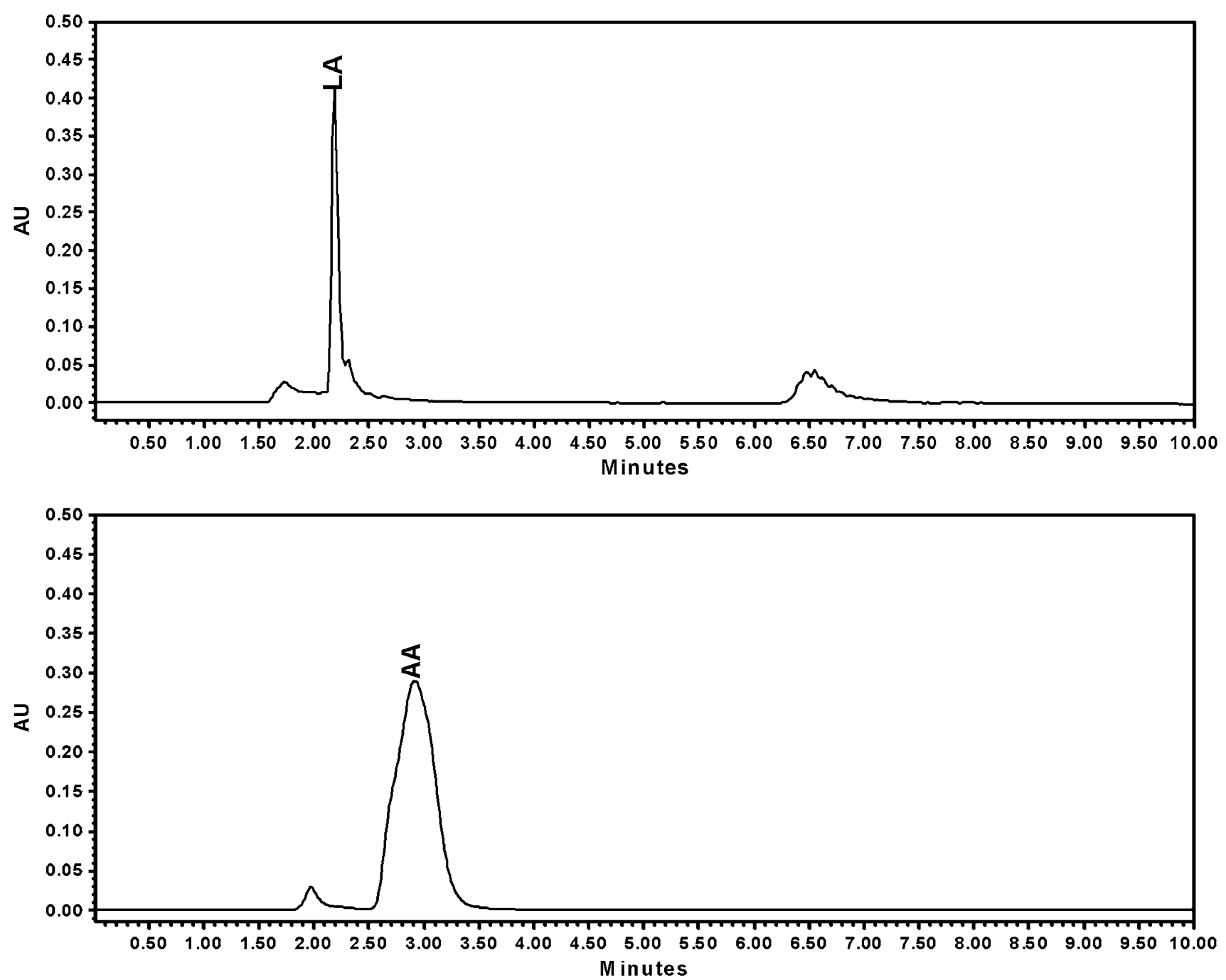

Fig. 1 Chromatograms of standard $0.1 \%$ lactic acid (LA) and $1.0 \%$ acetic acid (AA) solutions

dried WFFO and LAFFO as well as between pre-fermentation mixture and the final product of each category (WFFO and LAFFO) were also determined.

\section{Results and discussion}

Microbiological status

SPC and population of LAB, yeast and hazardous microorganisms (total and faecal coliform bacteria, Staphylococcus and Clostridium) determined in fresh FOW, fresh whey, WFFO and LAFFO have been presented in Table 1. A high degree of contamination of hazardous microorganisms was found in both fresh FOW and fresh whey. FOW appeared as a more dangerous pollutant than whey because of containing relatively higher amount of faecal coliform bacteria, Staphylococcus and Clostridium. The presence of these microorganisms in drinking water or food is of great concern for public health (Prescott et al. 2002). However, both the wastes contained a small amount of yeast and moderate to high amount of LAB. Preliminary experiments to ferment FOW without addition of any inoculum indicated that the population of $\mathrm{LAB}$ present in the FOW grew to a maximum of up to $6.61 \pm 0.5 \log \mathrm{CFU} / \mathrm{g}$ during fermentation, which alone was inadequate to carry out fermentation to a desirable end point. However, addition of an inoculum like whey [with high amount of LAB $(8.73 \pm 0.14 \log \mathrm{CFU} / \mathrm{ml})]$ to FOW prompted the steady growth of LAB resulting in quick completion of the fermentation process. Preliminary investigation also indicated that a significant proportion of LAB of the whey was represented by Lactobacillus sp. (5.36 \pm 0.08 $\log \mathrm{CFU} / \mathrm{ml}$ ) rendering it a viable inoculum for fermentation. In both treatments, LAB became the dominant microorganisms at the end of fermentation, which was an indication of a successful fermentation process (Faid et al. 1994, 1997; 
Table 1 Microbial population dynamics in the FOW, whey, cane molasses and fermented products
Data are means of three replicates $\pm \mathrm{SD}$. $N D$ Not detected

\begin{tabular}{lllllc}
\hline Microorganisms & $\begin{array}{l}\text { Fresh FOW } \\
\text { CFU/g) }\end{array}$ & $\begin{array}{l}\text { Fresh whey }(\log \\
\text { CFU/ml) }\end{array}$ & $\begin{array}{l}\text { Cane molasses } \\
(\log \text { CFU/g) }\end{array}$ & $\begin{array}{l}\text { WFFO (log } \\
\text { CFU/g) }\end{array}$ & $\begin{array}{l}\text { LAFFO (log } \\
\text { CFU/g) }\end{array}$ \\
\hline $\begin{array}{l}\text { Standard plate } \\
\text { count }\end{array}$ & $7.87 \pm 0.03$ & $8.73 \pm 0.09$ & $5.57 \pm 0.63$ & $8.80 \pm 0.05$ & $8.7 \pm 0.09$ \\
Total coliform & $7.61 \pm 0.03$ & $6.67 \pm 0.01$ & $\mathrm{ND}$ & $\mathrm{ND}$ & $1.73 \pm 0.06$ \\
Faecal coliform & $6.62 \pm 0.01$ & $5.62 \pm 0.04$ & $\mathrm{ND}$ & $\mathrm{ND}$ & $\mathrm{ND}$ \\
Staphylococcus & $5.13 \pm 0.07$ & $4.76 \pm 0.04$ & $1.2 \pm 0.11$ & $1.44 \pm 0.03$ & $1.56 \pm 0.03$ \\
Clostridium & $4.02 \pm 0.05$ & $1.81 \pm 0.09$ & $4.04 \pm 0.21$ & $0.69 \pm 0.03$ & $1.30 \pm 0.06$ \\
LAB & $5.85 \pm 0.02$ & $8.73 \pm 0.14$ & $1.77 \pm 0.57$ & $8.80 \pm 0.09$ & $8.67 \pm 0.04$ \\
Yeast & $2.02 \pm 0.07$ & $1.96 \pm 0.03$ & $1.34 \pm 0.07$ & $6.51 \pm 0.07$ & $5.64 \pm 0.01$ \\
\hline
\end{tabular}
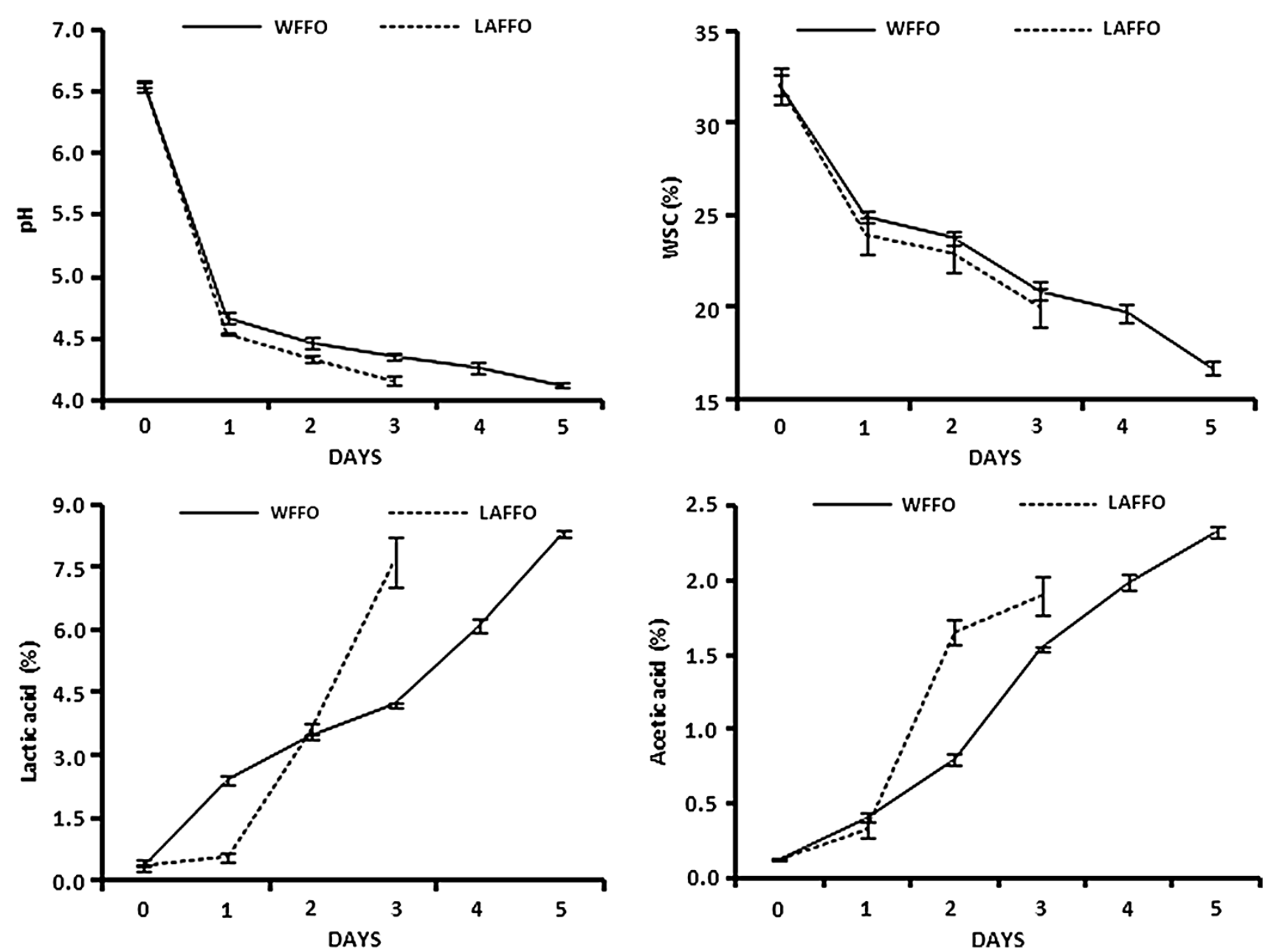

Fig. 2 Changes in biochemical parameters during fermentation

Burns and Bagley 1996). Acid-tolerant yeast also grew in the medium (3.39-4.40 log CFU/g in the middle of fermentation), but failed to inhibit the growth of LAB (7.97-8.23 log $\mathrm{CFU} / \mathrm{g}$ in the middle of fermentation) in the WFFO group. The results of the present study indicate that fermentation by whey or L. acidophilus can substantially reduce the population of Staphylococcus, Clostridium and coliform bacteria, with the latter being totally removed from the WFFO and faecal coliform removed from the LAFFO. Increase in the

population of $\mathrm{LAB}$ and production of organic acids create a low $\mathrm{pH}$ during fermentation, which probably resulted in conditions unfavourable to the above hazardous microorganisms (Nwad et al. 2008; El Jalila et al. 2001).

Changes in biochemical parameters

Changes observed in the level of $\mathrm{pH}$, WSC, LA and AA contents during fermentation have been presented in Fig. 2. 
Table 2 Biochemical composition of the FOW, prefermentation mixture and the fermented products (WFFO, LAFFO)

a,b,c Dissimilar superscripts in a row indicate significant difference $(P<0.05)$

\begin{tabular}{lrrrr}
\hline $\begin{array}{l}\text { Parameters (percent dry } \\
\text { matter) }\end{array}$ & \multicolumn{1}{l}{ FOW } & $\begin{array}{l}\text { Pre-fermentation } \\
\text { mixture }\end{array}$ & \multicolumn{1}{l}{ WFFO } & \multicolumn{1}{l}{ LAFFO } \\
\hline Crude protein & $40.1 \pm 0.23$ & $32.32 \pm 0.27^{\mathrm{a}}$ & $30.67 \pm 0.48^{\mathrm{b}}$ & $31.08 \pm 0.13^{\mathrm{b}}$ \\
Crude lipid & $27.09 \pm 0.92$ & $21.29 \pm 0.19^{\mathrm{a}}$ & $21.69 \pm 0.35^{\mathrm{a}}$ & $21.09 \pm 0.7^{\mathrm{a}}$ \\
Crude fibre & $1.85 \pm 0.11$ & $1.78 \pm 0.06^{\mathrm{a}}$ & $1.39 \pm 0.21^{\mathrm{b}}$ & $1.62 \pm 0.04^{\mathrm{ab}}$ \\
Moisture & $11.02 \pm 0.27$ & $9.68 \pm 0.12^{\mathrm{a}}$ & $10.86 \pm 0.33^{\mathrm{b}}$ & $10.65 \pm 0.43^{\mathrm{b}}$ \\
Ash & $2.84 \pm 0.13$ & $3 \pm 0.09^{\mathrm{a}}$ & $2.93 \pm 0.21^{\mathrm{b}}$ & $2.95 \pm 0.14^{\mathrm{c}}$ \\
Nitrogen-free extract & $17.08 \pm 0.96$ & $31.92 \pm 0.17^{\mathrm{a}}$ & $32.61 \pm 0.02^{\mathrm{b}}$ & $32.59 \pm 0.37^{\mathrm{b}}$ \\
Free amino acid & $0.17 \pm 0.03$ & $0.24 \pm 0.02^{\mathrm{a}}$ & $1.13 \pm 0.26^{\mathrm{b}}$ & $0.52 \pm 0.05^{\mathrm{c}}$ \\
Lactic acid (LA) & $0.1 \pm 0.03$ & $0.19 \pm 0.88^{\mathrm{a}}$ & $20.97 \pm 0.69^{\mathrm{b}}$ & $16.08 \pm 0.15^{\mathrm{c}}$ \\
Acetic acid (AA) & $1.1 \pm 0.06$ & $1.12 \pm 0.04^{\mathrm{a}}$ & $4.91 \pm 0.04^{\mathrm{b}}$ & $4.01 \pm 0.05^{\mathrm{c}}$ \\
\hline
\end{tabular}

Table 3 Mould and yeast population ( $\log \mathrm{CFU} / \mathrm{g})$ in the fresh and fermented waste

\begin{tabular}{|c|c|c|c|c|}
\hline \multirow[t]{2}{*}{ Treatments } & \multicolumn{2}{|c|}{$\begin{array}{l}\text { After } 1 \mathrm{~h} \text { exposure to } \\
\text { air }\end{array}$} & \multicolumn{2}{|c|}{ After 5 days of incubation } \\
\hline & $\begin{array}{l}\text { Mixture of } \\
\text { mould and } \\
\text { yeast }\end{array}$ & Yeast & $\begin{array}{l}\text { Mixture of } \\
\text { mould and } \\
\text { yeast }\end{array}$ & Yeast \\
\hline Control & $0.60 \pm 0.03$ & ND & $4.49 \pm 0.1$ & $1.53 \pm 0.06$ \\
\hline $\begin{array}{l}\text { Fresh fish } \\
\text { offal }\end{array}$ & ND & ND & $3.00 \pm 0.07$ & $0.30 \pm 0.12$ \\
\hline WFFO & ND & ND & ND & ND \\
\hline LAFFO & ND & ND & ND & ND \\
\hline
\end{tabular}

On dry matter basis. $N D$ not detectable

Fermentation was terminated after the 3rd day in the LAFFO when the mixture attained a $\mathrm{pH}$ value of $4.15 \pm 0.04$. However, production of LA and AA was relatively less and the $\mathrm{pH}$ value was significantly higher $(4.35 \pm 0.04)$ on the 3rd day in WFFO as compared to LAFFO. Therefore, the fermentation was continued till the $\mathrm{pH}$ attained a value of $4.12 \pm 0.01$ on the 5 th day. The desired level of $\mathrm{pH}$ indicative of completion of fermentation is 4.0-4.2. Within this $\mathrm{pH}$ range, the fermented products are safe from spoilage and fit for use as feedstuff for animals (Lee et al. 2004; Yashoda et al. 2001). LA and AA are the major metabolites responsible for reduction of $\mathrm{pH}$ in the fermentation mixture. In the present study, LA was generated in higher quantity than AA in both the fermentation mixtures because of the capacity of LAB to produce LA as the major metabolite (Piard and Desmazeaud 1991). Kung and Shaver (2001) also observed that LA was generated in higher quantity than AA in the silage fermentation process. LA appeared to be primarily responsible for the drop of silage $\mathrm{pH}$, because acidity of LA was stronger than that of other organic acids generated during the silage fermentation process. L. acidophilus is homofermentative in nature and produced LA as the only organic acid, thereby resulting in the fast and efficient reduction of $\mathrm{pH}$ on the $3 \mathrm{rd}$ day of fermentation in the present study (Prescott et al. 2002; Weinberg and Muck 1996). However, in the WFFO group adequate amount of LA was not produced to reduce $\mathrm{pH}$ to the desired level on the $3 \mathrm{rd}$ day of fermentation. Fermentation of milk to yogurt formation is carried out principally by homofermentative LAB (Moreira et al. 2000; $\mathrm{Ng}$ et al. 2011), and whey being a by-product of this production system is also expected to carry same homofermentative group of bacteria. But unlike active pure culture of L. acidophilus, the metabolic activity of LAB present in the whey was not strong enough to produce an adequate quantity of LA required to reduce $\mathrm{pH}$ to the desired level within 3 days of fermentation. When fermentation was extended for two more days in the WFFO group, an adequate quantity of LA accumulated and $\mathrm{pH}$ was reduced to the desired level. Since AA was also detected in both the fermentation mixtures, the presence of some heterofermentative LAB or other AA-producing microorganism in these mixtures could not be ruled out. The probable source of these microorganisms was either fish offal or molasses. The accumulation of AA in relatively higher amount in WFFO as compared to LAFFO is probably helpful for its better protection against spoilage under aerobic condition (Filya 2003; Kung et al. 2003). There was no significant difference in WSC content between the two fermentation groups till the 3rd day of fermentation, indicating that the carbohydrate utilization rate was the same in both the groups. However, the WSC level in WFFO decreased to a level lower than that found on the 3rd day in the LAFFO mixture when fermentation was continued up to day 5 .

Crude protein (CP), crude lipid (CL), moisture and NFE of fresh whey and cane molasses (\% wet weight basis) were, respectively, 2.13, 1.96, 90.17, 5.74 and 2.86, 1.37, 14.0, 78.14. Proximate compositions of FOW, pre-fermented mixture and the two fermented products of fish offal (WFFO and LAFFO) have been presented in Table 2. Significant variations were observed in the proximate composition between the pre-fermentation mixture and the fermented products, except in crude lipid and ash content. Crude protein level reduced significantly in both the 
fermented products, as compared to the pre-fermented mixture, but reduction was restricted only to $1.24 \%$ (in LAFFO) and $1.65 \%$ (in WFFO). Free amino acid level significantly increased both in WFFO and LAFFO as compared to the pre-fermentation mixture. Free amino acid level of WFFO was significantly higher than that of LAFFO. Crude protein level in the fermented products decreased from the pre-fermentation mixture, probably due to utilization of a part of the protein by microorganisms as nutrient source in their metabolism. Extracellular proteolytic activity of the fermenting microflora might be responsible for the breakdown of a part of the protein resulting in the reduction of crude protein and increase of free amino acid level in the fermented products (Savijoki et al. 2006; Haq and Mukhtar 2006). However, it increases digestibility of the fermented products when these are used as feed ingredient. Excess free amino acids can also act as potential chemo-attractants in feed (Ramírez-Ramírez et al. 2008; Lian et al. 2005). Crude fibre level was also significantly reduced in WFFO as compared to pre-fermented product probably due to cellulolytic microbial action during fermentation (Ghosh et al. 2004). Based on the free amino acid and crude fibre level, WFFO appears to be a better digestible protein source as compared to LAFFO and comparable to fishmeal, though the latter contains a higher level of crude protein (Kaviraj et al. 2012).

\section{Aerobic stability}

There was no growth of mould and yeast in the samples, when these were incubated in plates covered by a lid. However, in plates exposed to open air (temperature 26-29 ${ }^{\circ} \mathrm{C}$ and humidity $68-72 \%$ ), both mould and yeast grew profusely in the control and moderately in fresh FOW, but failed to grow on the fermented products (Table 3). Aerobic spoilage not only reduces nutritional value of the fermented product, but also increases the risk of proliferation of potential pathogenic or otherwise undesirable microorganisms (Driehuis and Oude Elferink 2000). Yeast serves as an initiator of spoilage through oxidization of preserving acids and increase in $\mathrm{pH}$ of the medium, which in turn help mould to grow (Woolford 1990; Pahlow et al. 2003). Such growth of yeast and mould reduces feed value and palatability of the fermented products and produces negative effect on animal health (Oude Elferink et al. 2000). The shelf value of the fermented products also depends to a large extent on WSC content left after fermentation, which can act as the substrate for growth of mould when exposed to air. Accumulation of LA and AA in sufficient quantities in the fermented products (Table 2) can create antagonistic effects on the growth of yeast and mould (Moon 1983), rendering aerobic stability to the products.

\section{Conclusions}

It is concluded from the present study that whey, an easily available by-product of milk industry, is a good source of LAB with significant proportion of Lactobacillus sp., which renders it a viable inoculum to ferment FOW. Fermentation of FOW by whey results in marginal loss of crude protein and almost no loss of crude lipid in the fermented product. The WFFO is also microbiologically safe, low in fibre content and rich in free amino acid level and is therefore suitable for use as feed supplement in animal feed formulation.

Acknowledgments Financial assistances received from UGC, New Delhi, and DST PURSE, Govt. of India, for this research are gratefully acknowledged.

Conflict of interest The authors declare that there is no competing interest.

Open Access This article is distributed under the terms of the Creative Commons Attribution License which permits any use, distribution, and reproduction in any medium, provided the original author(s) and the source are credited.

\section{References}

Bairagi A, Sarkar Ghosh K, Sen SK, Ray AK (2002) Duckweed (Lemna polyrhiza) leaf meal as a source of feedstuff in formulated diets for rohu (Labeo rohita) fingerlings after fermentation with a fish intestine bacterium. Bioresour Technol $85: 17-24$

Burns JC, Bagley CP (1996) Cool-season grasses for pasture. In: Moser LE, Buxton DR, Casler MD (eds) Cool season forage grasses. American Society of Agronomy, Crop Science Society of America, Soil Science Society of America, Madison pp 321-355

Cappuccino J, Sherman N (2007) Microbiology: a laboratory manual. Pearson Education, New Delhi, p 14

Chou LS, Weimer B (1999) Isolation and characterization of acid and bile tolerant isolates from strains of Lactobacillus acidophilus. J Dairy Sci 82:23-31

Delves-Broughton J (1990) Nisin and its uses as a food preservative. Food Technol 44:100-117

Dremetsika AV, Siskos PA, Bakeas EB (2005) Determination of formic and acetic acid in the interior atmosphere of display cases and cabinets in Athens museums by reverse phase high performance liquid chromatography. Indoor Built Environ 14:51-58

Driehuis F, Oude Elferink SJWH (2000) The impact of quality of silage on animal health and food safety: a review. Vet Q 22: 212-217

Driehuis F, Oude Elferink SJWH, Van Wikselaar PG (2001) Fermentation characteristics and aerobic stability of grass silage inoculated with Lactobacillus buchneri, with or without homofermentative lactic acid bacteria. Grass Forage Sci 56:330-343

El Jalila MH, Faid M, Elyachioui M (2001) A biotechnological process for treatment and recycling poultry wastes manure as a feed ingredient. Biomass Bioenerg 21:301-309

Faid M, Karani H, Elmarrakchi A, Achkari-Begdouri A (1994) A biotechnological process for the valorization of fish waste. Bioresour Technol 49:237-241 
Faid M, Zouiten A, Elmarrakchi A, Achkari-Begdouri A (1997) Biotransformation of fish waste into a stable feed ingredient. Food Chem 60:13-18

Filya I (2003) The effect of Lactobacillus buchneri and Lactobacillus plantarum on the fermentation, aerobic stability, and ruminal degradability of low dry matter corn and sorghum silages. J Dairy Sci 86:3575-3581

Ghosh K, Sen SK, Ray AK (2004) Growth and survival of rohu, Labeo rohita (Hamilton, 1822) spawn fed diets fermented with intestinal bacterium, Bacillus circulans. Acta Ichthyol Piscat 34(2):155-165

Gomez KA, Gomez AA (eds) (1984) Statistical procedures for agricultural research, 2nd edn. Wiley, NY

Gonzalez-Siso MI (1996) The biotechnological utilization of cheese whey: a review. Bioresour Technol 57:1-17

Goyal N, Gandhi DN (2009) Comparative analysis of Indian paneer and cheese whey for electrolyte whey drink. World J Dairy Food Sci 4(1):70-72

Hammoumi A, Faid M, Elyachioui M, Amarouch H (1998) Characterization of fermented fish waste used in feeding trials with broilers. Process Biochem 33(4):423-427

Haq IU, Mukhtar H (2006) Biosynthesis of protease from Lactobacillus paracasei: kinetic analysis of fermentation parameters. Indian J Biochem Biophys 43:377-381

Helrich W (ed) (1990) Official methods of analyses. Association of Official Analytical Chemists, Washington DC

Kaviraj A, Mondal K, Mukhopadhyay PK, Turchini GM (2012) Impact of fermented mulberry leaf and fish offal in diet formulation of Indian major carp (Labeo rohita). Proc Zool Soc 66(1):64-73

Kung L, Shaver R (2001) Interpretation and use of silage fermentation analyses reports. In: Focus on forage, Forage management fact sheet, University of Wisconsin, Madison, vol 3, No. 13. Available via http://www.uwex.edu/ces/crops/uwforage/Fermen taion.html. Accessed 21 Sept 2013

Kung L, Taylor CC Jr, Lynch MP, Neylon JM (2003) The effect of treating alfalfa with Lactobacillus buchneri 40788 on silage fermentation, aerobic stability, and nutritive value for lactating dairy cows. J Dairy Sci 86:243-336

Lee KS, Lee KY, Oh CS, Lee DG, Kim YJ (2004) Effect of aeration for the probiotic feed production from food wastes by Lactobacillus acidophilus and Saccharomyces cerevisiae. J Korea Org Waste Recycl Counc 11(4):114-119

Lian PZ, Lee CM, Park E (2005) Characterization of squid-processing by-product hydrolysate and its potential as aquaculture feed ingredient. J Agric Food Chem 53:5587-5592

Marwaha SS, Kennedy JF (1988) Whey pollution problem and potential utilization. Int J Food Sci Technol 23:323-336

McHugh J, Dumont SN, Julie P, Nguyen AL, Levesque S, Carrier A (2006) New and simple HPLC method for the determination of lactic acid content in ciprofloxacin injection. J Liq Chromatogr Relat Technol 29:1905-1916

Mondal K, Kaviraj A, Mukhopadhyay PK, Datta M, Sengupta C (2007) Evaluation of fermented fish-offal in formulated diet of the Indian major carp, rohu, Labeo rohita (Hamilton). Acta Ichthyol Piscat 37:99-105

Mondal K, Kaviraj A, Mukhopadhyay PK (2008) Evaluation of fermented fish- offal in the formulated diet of the freshwater catfish Heteropneustes fossilis. Aquac Res 39:1443-1449

Moon NJ (1983) Inhibition of the growth of acid tolerant yeasts by acetate, lactate and propionate and their synergistic mixtures. J Appl Bacteriol 55:453-460

Moore S, Stein WH (1948) Photometric ninhydrin method for use in the chromatography of amino acid. J Biol Chem 176: 367-388
Moreira M, Abraham A, De' Antoni G (2000) Technological properties of milks fermented with thermophilic lactic acid bacteria at suboptimal temperature. J Dairy Sci 83:395-400

Murphy PT, Moore KJ, Richard TL, Bern CP (2007) Enzyme enhanced solid-state fermentation of kenaf core fiber for storage and pretreatment. Bioresour Technol 98:3106-3111

$\mathrm{Ng} \mathrm{E}$, Yeung M, Tong P (2011) Effect of starter cultures on the survival of Lactobacillus acidophilus. Int J Food Microbiol 145(1):169-175

Nwad AD, Faid M, Bouseta A, Zinedine A (2008) Effects of controlled lactic acid fermentation on the microbiological and chemical quality of Moroccan sardines (Sardina pilchardus). Int J Agric Biol 10(1):21-27

Oude Elferink SJWH, Driehuis F, Gottschal JC, Spoelstra SF (2000) Silage fermentation process and their manipulation. In: t'Mannetje L (ed) Silage making in the tropics with particular emphasis on smallholders. In: Proceedings of the FAO electronic conference on tropical silage, FAO, Rome, pp 17-30

Pahlow G, Muck RE, Driehuis F, Oude Elferink SJWH, Spoelstra SF, Madison HJH (2003) Microbiology of ensiling. In: Buxton DR, Muck RE (eds) Silage Science and Technology. American Society of Agronomy, Madison, pp 31-93

Piard JC, Desmazeaud M (1991) Inhibiting factors produced by lactic acid bacteria: 1. Oxygen metabolites and catabolism end products. Lait 71:525-541

Prescott LM, Harley JP, Klein DA (2002) Microbiology, 5th edn. McGraw-Hill, London

Pyar H, Peh KK, Liong M (2011) Inhibitory effect of metabolites from probiotics Lactobacillus acidophilus strains on growth of pathogenic bacteria. J Pharmacol Toxicol 6(5):533-540

Ramírez-Ramírez JC, Huerta S, Arias L, Prado A, Shirai K (2008) Utilization of fisheries by-catch and processing wastes for lactic acid fermented silage and evaluation of degree of protein hydrolysis and in vitro digestibility. Rev Mex Ing Quím 7:195-204

Samaddar A, Mondal K, Kaviraj A (2011) Evaluation of fermented mixture containing fish offal meal in compound diets for the freshwater catfish Mystus vittatus (Bloch). Proc Zool Soc 64:117-123

Savijoki K, Ingmer H, Varmanen P (2006) Proteolytic systems of lactic acid bacteria. Appl Microbiol Biotechnol 71:394-406

Stiles ME (1996) Biopreservation by lactic acid bacteria. Antonie van Leeuwenhoek 70:331-345

Vidotti RM, Carneiro DJ, Viegas EM (2002) Acid and fermented silage characterization and determination of apparent digestibility coefficient of crude protein for Piaractus mesopotamicus. J World Aqua Soc 33:57-62

Weinberg ZG, Muck RE (1996) New trends and opportunities in the development and use of inoculants for silage. FEMS Microbiol Rev 19:53-68

Woolford MK (1990) The detrimental effects of air on silage. J Appl Bacteriol 68:101-116

Yashoda KP, Sachindra NM, Rao D, Mahendrakar NS (2001) Changes in microbial population during fermentation of silk worm pupae. Sericologia 41(2):253-261

Ayan Samaddar He did his M. Sc in Zoology from the University of Kalyani in 2009 and is presently doing doctoral research under the supervision of the second author Dr. Anilava Kaviraj.

Anilava Kaviraj $\mathrm{He}$ is a Professor of Zoology in the University of Kalyani. Prof. Kaviraj is faculty in the University of Kalyani since 1984 and is presently engaged in researches in the field of fisheries and environmental pollution. 